\title{
Mg-enriched erythrite from Bou Azzer, Anti-Atlas Mountains, Morocco: geochemical and spectroscopic characteristics
}

\author{
Magdalena Dumańska-Słowik ${ }^{1} \cdot$ Adam Pieczka $^{1} \cdot$ Lucyna Natkaniec-Nowak $^{1} \cdot$ \\ Piotr Kunecki $^{2}$ - Adam Gawel ${ }^{1}$ - Wiesław Heflik ${ }^{1}$ • Wojciech Smoliński ${ }^{1}$ • \\ Gabriela Kozub-Budzyń ${ }^{1}$
}

Received: 17 March 2017 / Accepted: 31 October 2017 / Published online: 10 November 2017

(c) The Author(s) 2017. This article is an open access publication

\begin{abstract}
Supergene Mg-enriched erythrite, with an average composition $\left(\mathrm{Co}_{2.25} \mathrm{Mg}_{0.58} \mathrm{Ni}_{0.14} \mathrm{Fe}_{0.04} \mathrm{Mn}_{0.02} \mathrm{Zn}_{0.02}\right)$ $\left(\mathrm{As}_{1.97} \mathrm{P}_{<0.01} \mathrm{O}_{8}\right) \cdot 8 \mathrm{H}_{2} \mathrm{O}$, accompanied by skutterudite, roselite and alloclasite, was identified in a pneumo-hydrothermal quartz-feldspar-carbonate matrix within the ophiolite sequence of Bou Azzer in Morocco. The unit cell parameters of monoclinic Mg-enriched erythrite [space group $C 2 / m, a=10.252(2) \AA, b=13.427(3) \AA, c=4.757(3) \AA, \beta$ $\left.=105.12(1)^{\circ}\right]$ make the mineral comparable with erythrite from other localities. The composition of the sample represents the solid solution between erythrite, hörnesite and annabergite, that is, the nearest to the endmember erythrite. However, $\mathrm{Mg}$-enriched erythrite forming the crystal exhibits variable compositions, especially in $\mathrm{Mg}$ and $\mathrm{Co}$ contents, with $\mathrm{Mg}$ increasing from 0.32 up to $1.39 \mathrm{apfu}$, and Co decreasing from 2.53 to $1.50 \mathrm{apfu}$, which manifests in the fine compositional oscillatory zoning. It is the highest content of $\mathrm{Mg}$ in erythrite structure reported so far. The most intensive Raman active $\nu_{3}$ and $\nu_{1}$ bands, recorded for the crystal's zones with maximum $\mathrm{Mg}$ contents, occur at 865 and $800 \mathrm{~cm}^{-1}$ and are shifted towards higher wavenumbers, where normally hörnesite Raman bands appear. The characteristic oscillatory zoning texture results from varying contents of main and trace elements mobilized from the host
\end{abstract}

Editorial handling: A. Beran

Magdalena Dumańska-Słowik

dumanska@uci.agh.edu.pl

1 Faculty of Geology, Geophysics and Environmental Protection, AGH University of Science and Technology, Krakow 30-059, 30 Mickiewicz Av., Poland

2 Mineral and Energy Economy Research Institute, Polish Academy of Sciences, 7 Wybickiego Str., 31-261 Krakow, Poland ores (Co arsenides, mainly skutterudite) and rock-forming minerals (among others, dolomite) by the solutions in the oxidation zone of the ore deposits. The heating of the $\mathrm{Mg}$ enriched erythrite up to $1000{ }^{\circ} \mathrm{C}$ leads to the crystallization of the water-free $(\mathrm{Co}, \mathrm{Mg})_{3}\left(\mathrm{AsO}_{4}\right)_{2}$ phase.

Keywords Erythrite $\cdot$ Arsenate $\cdot$ Solid solution $\cdot$ Bou Azzer · Morocco

\section{Introduction}

The mining region of Bou Azzer is located in Ouarzazate, the southern province of Morocco, in the central belt of the Anti-Atlas Mountains. This area is known for its rich nickel and cobalt mineralization. Cobalt mining commenced here in 1928, and Bou Azzer remains one of the leaders in the extraction and processing of this metal worldwide. According to Hawkins (2006; vide Ahmed et al. 2009), about 8\% of the world's cobalt production comes from this region. Cobalt is a strategic element used in the following industries: modern materials (superalloys), electronics (component of electrodes in Li-ion batteries of various types), chemicals (catalysts, pigments and dyes), aviation (anti-corrosion material), and many others (see Vidmar 2011). Therefore, it is worthwhile continuing research on Co-bearing minerals to contribute to a better geological understanding of Co mineralization in this region and to facilitate further exploration of this metal.

The Bou Azzer region is also known to mineralogists because of an abundance of uncommon minerals and their parageneses. More than 200 minerals were identified in this area by the end of twentieth century (Smith 2001; Ahmed et al. 2009a). The majority of them represent $\mathrm{Co}-\mathrm{Ni}$ arsenides and arsenates. The most common 
arsenides are skutterudite $\left(\mathrm{CoAs}_{3}\right)$, safflorite $\left(\mathrm{CoAs}_{2}\right)$, löllingite $\left(\mathrm{FeAs}_{2}\right)$, nickeline (NiAs) and rammelsbergite $\left(\mathrm{NiAs}_{2}\right)$. Additionally, arsenopyrite (FeAsS) and gersdorffite (NiAsS) represent arsenosulphides, whereas erythrite and roselite $\left[\mathrm{Ca}_{2} \mathrm{Co}\left(\mathrm{AsO}_{4}\right)_{2} \cdot 2 \mathrm{H}_{2} \mathrm{O}\right]$ are the most common secondary arsenates (Ahmed et al. 2009a). Small Au-Ag deposits within quartz veins accompany the Co-Ni mineralization in the area.

Erythrite (so-called red cobalt), with the idealized formula $\mathrm{Co}_{3}\left(\mathrm{AsO}_{4}\right)_{2} \cdot 8 \mathrm{H}_{2} \mathrm{O}$, forms complete isostructural series with annabergite, $\mathrm{Ni}_{3}\left(\mathrm{AsO}_{4}\right)_{2} \cdot 8 \mathrm{H}_{2} \mathrm{O}$, and hörnesite, $\mathrm{Mg}_{3}\left(\mathrm{AsO}_{4}\right)_{2} \cdot 8 \mathrm{H}_{2} \mathrm{O}$, within the vivianite group of arsenate and phosphate minerals. All minerals forming the group crystallize in the monoclinic system with $C 2 / \mathrm{m}$ spacegroup symmetry (Wildner et al. 1996; Anthony et al. 2000; Capitelli et al. 2012). Erythrite is a typical secondary product of oxidation processes in $\mathrm{Co}, \mathrm{Ni}$ and As ore deposits (Jambor and Dutrizac 1995). It commonly forms radial or stellate aggregates composed of pink to violet acicular crystals. Apart from Bou Azzer in Morocco, it is also found in other localities, for example: Cobalt, Ontario, Canada; Schneeberg, Germany; Joachimsthal, Czech Republic; Cornwall, England; Blackbird Mine, Idaho, USA; Sara Alicia Mine, Mexico; Mount Cobalt, Queensland and the Dome Rock Copper Mine, South Australia. Erythrite with its unusual high contents of $\mathrm{ZnO}$ and $\mathrm{CuO}$ has been found in Ciechanowice (Miedzianka deposit, the Sudetes) in Poland (Ciesielczuk et al. 2004).

Although the economic role of Bou Azzer in cobalt production is significant, there are only limited scientific data on many secondary minerals and their parageneses in this region. Leblanc and his co-workers, studying the Proterozoic ophiolites of Bou Azzer (Leblanc 1976, 1981; Leblanc and Billaud 1982; Leblanc and Lbouabi 1988; Leblanc and Fischer 1990), focused mainly on the economic potential of Co-Ni mineralization. Capitelli et al. (2007) refined the X-ray single-crystal structure of Mgenriched erythrite from this region. Our study comprises comprehensive microscopic, powder X-ray diffraction (PXRD), electron probe micro-analysis (EPMA), simultaneous thermal analysis (STA) and Raman spectroscopy (RS) data performed on $\mathrm{Mg}$-enriched erythrite from Bou Azzer in order to identify detailed mineralogical and geochemical characteristics of the mineral and discuss its possible genesis. The zoned $\mathrm{Mg}$-enriched erythrite crystals, containing zones with the highest $\mathrm{Mg}$ content ever reported for the mineral erythrite, close on that score to the border $\mathrm{Mg}$ contents in erythrite, as a member of the erythrite-hörnesite solid solution series, seem to be important for any discussion of $\nu_{3}$ and $\nu_{1}$ band positions in Raman spectra.

\section{Geological setting}

The Co-Ni Bou Azzer Mining Complex is located about $50 \mathrm{~km}$ south of Ouarzazate in Central Morocco within the Anti-Atlas Mountains (Fig. 1). This complex extends to a distance of $60-70 \mathrm{~km}$. It includes more than 60 ore-bearing quartz-carbonate veins, occurring in the contact zones between Neoproterozoic serpentinized peridotites, quartz diorites and Precambrian volcanic rocks (Fig. 2), which are the oldest rocks in Morocco (Ahmed et al. 2009b). Bou Azzer deposits are hosted by ophiolite (Leblanc and Fischer 1990; Wilde et al. 2002) and classified as polymetallic, hydrothermal and volcanogenic, thus having a similar genesis to Ni-Co-Ag-As-Bi deposits of the Ontario vein type (Marshall and Watkinson 2000) or epigenetic $\mathrm{Cu}-\mathrm{Au}$ Co deposits from the Cobalt belt of Idaho (Kolkovski et al. 2003). The Ni-Co assemblage is mainly composed of skutterudite, rammelsbergite, nickeline and chalcopyrite. At the East Bou Azzer Mine, erythrite is found at a depth of $200 \mathrm{~m}$. The origin of this mineralization results from magmatic differentiation, hydrothermal activity and weathering (Lhoest 1995; Smith 2001). A complex polymetallic Co-Ni-As-Fe$\mathrm{Cu}-\mathrm{Au}-\mathrm{Ag}$ mineral deposit was formed during the Pan-African and Variscan tectonic event (En-Naciri et al. 1997). The age of Bou Azzer mineralization is still poorly constrained at $550 \mathrm{Ma}$ by $\mathrm{U}-\mathrm{Pb}$ dating of brannerite and at $218 \mathrm{Ma}$ by +/- $8 \mathrm{Ma}$ by ${ }^{40} \mathrm{Ar} /{ }^{39} \mathrm{Ar}$ dating on hydrothermal muscovite (see Gasquet et al. 2005).

\section{Materials and methods}

The three samples under investigation were examined under a binocular microscope to select proper material for research. One of the samples (Fig. 3a) was investigated using an Olympus BX 51 polarizing microscope with a magnification of $40 \times$ to $400 \times$, a scanning electron microscope/ energy-dispersive X-ray spectrometer (SEM-EDXS), PXRD, RS, STA, such as thermogravimetry (TG), differential thermogravimetry (DTG), differential thermal analysis (DTA) coupled with a quadrupole mass spectrometer (QMS), and EPMA methods.

Backscattered electron imaging was performed on polished, carbon-coated sections using an FEI Quanta 200 field emission gun SEM, equipped with an EDXS. The system was operated with an accelerating voltage of $20 \mathrm{kV}$ in a low-vacuum mode.

The PXRD studies, using a Rigaku Smart Lab 90 kW diffractometer with $\mathrm{Cu}-\mathrm{K} \alpha$ radiation, were performed on an erythrite-rich fraction separated from the sample. The device was equipped with a reflective graphite monochromator. The XRD patterns were recorded in the $2 \Theta$ range of $5-75^{\circ}$ with a step of $2 \%$ minute at a voltage of $45 \mathrm{kV}$ and a 


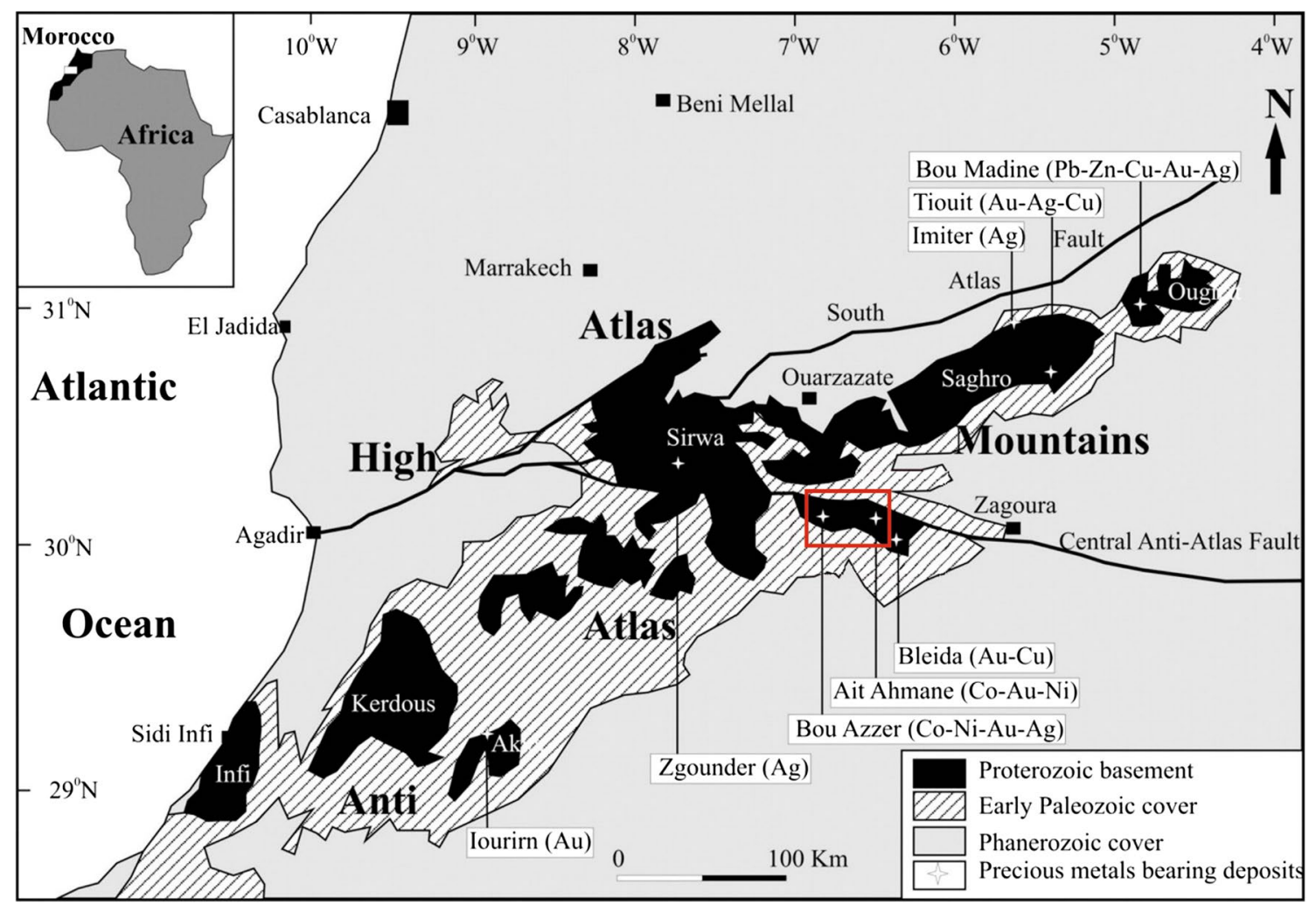

Fig. 1 Geological map of the Anti-Atlas Mountains in Southern Morocco with localization of the Bou Azzer region (Gasquet et al. 2005; Ahmed et al. 2009a)

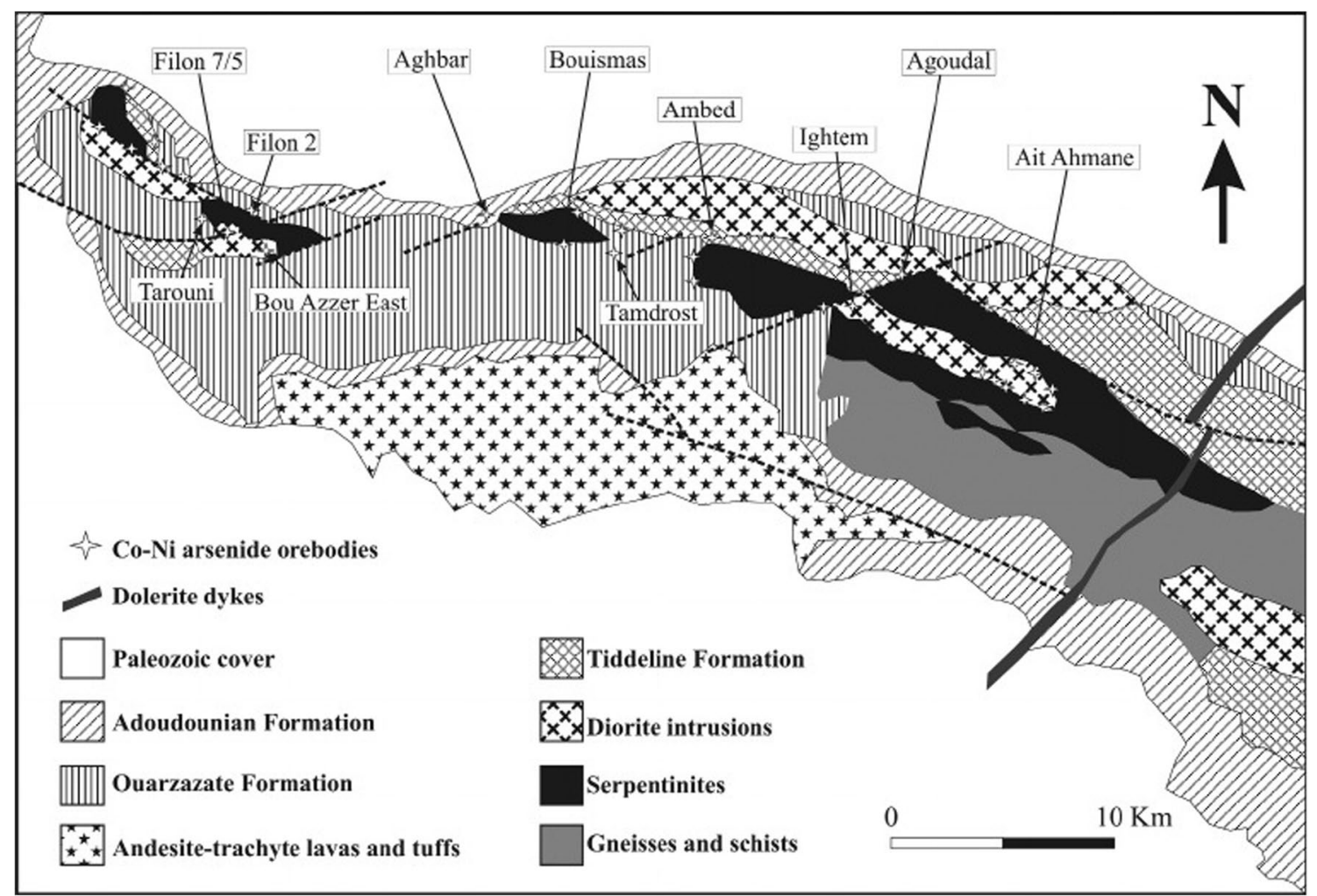

Fig. 2 Geological sketch map of Bou Azzer (Leblanc 1975; Ahmed et al. 2009a) 
Fig. 3 Pink-red Mg-enriched erythrite within a grey matrix from Bou Azzer: sample studied by authors, photo by Piotr Kunecki (a), elongated, prismatic crystals, Spirifer collection, photo by Jeffrey Scovil (b)
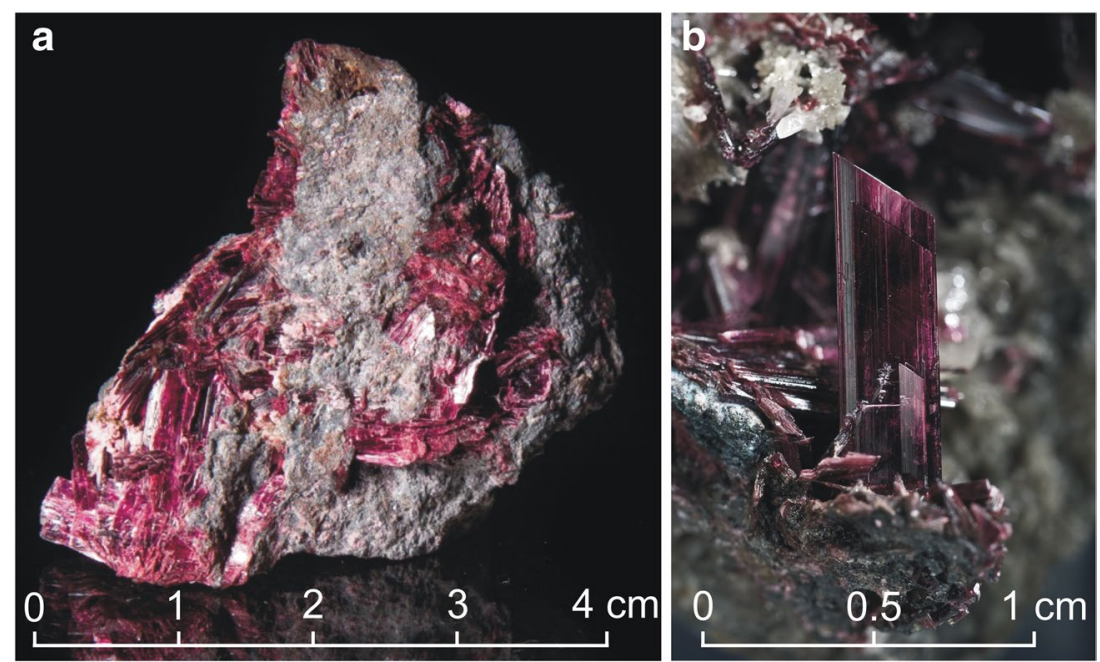

current of $200 \mathrm{~mA}$, with pure Si powder used as an internal standard. The unit cell parameters were refined first for the monoclinic space group $I 2 / m$ in accordance with data accessible from the ICDD database (card no. 33-413), using the least-squares method when applying the DHN-PDS program. However, the final unit cell refinement was made for $\mathrm{C} 2 / \mathrm{m}$ space-group symmetry in accordance with almost all structural investigations of vivianite-type phases, including erythrite, e.g., Wildner et al. (1996), Anthony et al. (2000) and Capitelli et al. (2012).

The STA measurements were carried out with an STA 449 F3 Jupiter (Netzsch). A 30-mg powdered, air-dried sample of $\mathrm{Mg}$-enriched erythrite was heated from 25 to $1000{ }^{\circ} \mathrm{C}$ in an alumina crucible, at $10{ }^{\circ} \mathrm{C} / \mathrm{min}$ in flowing $\left(40 \mathrm{~mL} \mathrm{~min}^{-1}\right)$ air. Analysis of the evolved gas was carried out using a Netzsch QMS 403C Aëolos QMS.

The EPMA were carried out with a JEOL Super Probe JXA-8230 operating in a wavelength-dispersive X-ray spectroscopy (WDXS) mode under the following conditions: accelerated voltage of $15 \mathrm{kV}$, beam current of $5 \mathrm{nA}$, beam size of $5 \mu \mathrm{m}$, peak count time of $10 \mathrm{~s}$ and a background time of $5 \mathrm{~s}$. EMPA operating conditions, standards and detection limits are presented in Table 1. The JEOL ZAF procedure was used for the matrix correction of the raw data. Atomic contents for the formulae of Mg-enriched erythrite were calculated on the basis of $8 \mathrm{O}$ atoms per formula unit (apfu), with the assumed presence of $8 \mathrm{H}_{2} \mathrm{O}$ molecules pfu. Compositional WDXS maps of erythrite in a $396 \mu \mathrm{m} \times 288 \mu \mathrm{m}$ area were collected using an accelerating voltage of $15 \mathrm{kV}$, a dwell time of $10 \mathrm{~ms}$, a step size of $0.33 \mu \mathrm{m}$, and a focus beam.

Raman spectra of Mg-enriched erythrite were recorded on clean cleavage surfaces of the crystals and a polished brass mount used for EMPAs, using a Thermo Scientific DXR Raman microscope featuring $10 \times, 50 \times$ and $100 \times$ magnification objectives. The sample was excited with a 532-nm laser
Table 1 EMPA conditions for Mg-enriched erythrite

\begin{tabular}{lllll}
\hline Element & Signal & WDXS crystal & Calibrant & $\begin{array}{l}\text { Detection } \\
\text { limit* }[\mathrm{ppm}]\end{array}$ \\
\hline $\mathrm{As}$ & $\mathrm{L} \alpha$ & $\mathrm{TAP}$ & $\mathrm{AlAsO}_{4}$ & 400 \\
$\mathrm{Co}$ & $\mathrm{K} \alpha$ & LIFH & $\mathrm{Co}$ & 170 \\
$\mathrm{Fe}$ & $\mathrm{K} \alpha$ & LIFL & Hematite & 170 \\
$\mathrm{Mg}$ & $\mathrm{K} \alpha$ & $\mathrm{TAPH}$ & Periclase & 100 \\
$\mathrm{Mn}$ & $\mathrm{K} \alpha$ & LIFL & Manganese & 150 \\
$\mathrm{Ni}$ & $\mathrm{K} \alpha$ & LIF & NiO & 320 \\
$\mathrm{P}$ & $\mathrm{K} \alpha$ & PETJ & Apatite & 105 \\
$\mathrm{Zn}$ & $\mathrm{K} \alpha$ & LIFL & ZnS & 300 \\
\hline
\end{tabular}

* Detection limits were determined by using JEOL software for $3 \sigma$ confidence level

with power from 10 to $20 \mathrm{~mW}$; exposure time was $3 \mathrm{~s}$, the number of exposures was 10 , and the laser focus diameter was approximately $2-1 \mu \mathrm{m}$. The spectra were corrected for background by the sextic polynomial method using Omnic software.

\section{Results}

\section{Optical and SEM observations}

The studied erythrite occurs as elongated, prismatic, platelike or needle-shaped pink-red-violet crystals with sizes up to $10 \mathrm{~mm}$ in length and $2-3 \mathrm{~mm}$ in width (Fig. 3a, and b). The crystals form radial or stellate aggregates within a grey quartz-feldspar-carbonate matrix, with subordinate muscovite and chlorite. In the matrix, erythrite is accompanied by skutterudite, roselite and alloclasite (Fig. 4a, and b). Erythrite is transparent with a glassy lustre; under an optical microscope, it shows a pale pink pleochroism. Associated 
Fig. 4 BSE images of Mgenriched erythrite (Er) with coexisting phases, such as skutterudite (Sk), roselite (Ro), alloclasite $(\mathrm{Al})$ and quartz $(\mathrm{Qtz})$
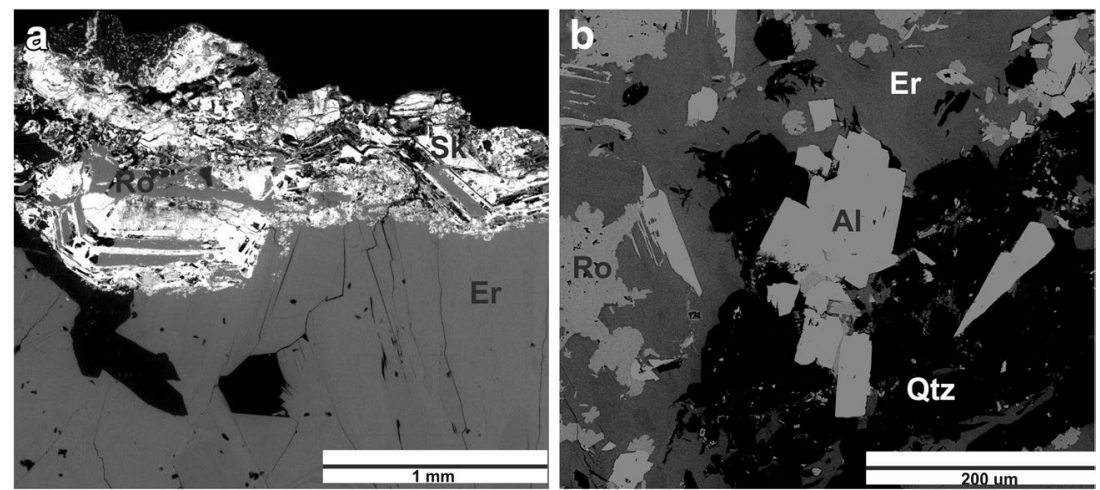

quartz most often occurs in the form of irregular crystals, but rarely is it euhedral. K-feldspars are represented mainly by euhedral adularia with characteristic zoning. In the vicinity of erythrite, they commonly occur as glomeroblasts. Carbonates, i.e., calcite and dolomite, fill interstices between As-bearing minerals. Chlorite commonly accompanies ore minerals. In back-scattered electron (BSE) images, the studied erythrite crystals are heterogeneous with fine compositional oscillatory zoning (Fig. 5a-c). The individual zones are thin, reaching only several micrometres in width. They are invisible under transmitted light. Lighter bands show Co as the dominant component, while $\mathrm{Ni}$ and $\mathrm{Mg}$ are subordinate; in the darkest bands, $\mathrm{Mg}$ distinctly increases to reach concentrations comparable to those of $\mathrm{Co}$, whereas $\mathrm{Ni}$ is on the same order as the lighter bands.

\section{PXRD}

The PXRD pattern recorded for a powdered sample revealed only the presence of erythrite (Fig. 6). The positions of all $\mathrm{X}$-ray reflections and their intensities are very similar to the ideal synthetic erythrite (card no. 33-413 from the ICDD database). The unit cell parameters, refined for the monoclinic system space group $C 2 / m$, are as follow: $a=10.252(2)$ $\AA, b=13.427(3) \AA, c=4.757(3) \AA, B=105.12(1)^{\circ}$, $\mathrm{V}=631.93 \AA$. The PXRD pattern recorded for the erythrite sample after heating to $1000{ }^{\circ} \mathrm{C}$ revealed the presence of the completely dehydrated phase $(\mathrm{Co}, \mathrm{Mg})_{3}\left(\mathrm{AsO}_{4}\right)_{2}$.

\section{Thermal analyses}

The results of the thermogravimetric analysis of erythrite is shown in Fig. 7. There is a $21 \mathrm{wt} \%$ loss at $125-250{ }^{\circ} \mathrm{C}$ and a 2 wt $\%$ loss at $250-325^{\circ} \mathrm{C}$. These two steps of mass loss are connected with the gradual dehydration of the mineral. In the erythrite structure, water molecules occupy two independent sites, which give rise to two independent $\mathrm{O}-\mathrm{H}$ bonds (Frost et al. 2003a). At $650-725^{\circ} \mathrm{C}$, there is sharp exothermic DTA peak, which can be related to the recrystallization of water-free $(\mathrm{Co}, \mathrm{Mg})_{3}\left(\mathrm{AsO}_{4}\right)_{2}$. Minor mass loss occurs in the range of $785-900{ }^{\circ} \mathrm{C}$, which is caused by the volatilization of As in varying amounts (Földvàri 2011).

\section{Chemical analyses (EPMAs)}

The distinct oscillatory zoning in the studied erythrite (Fig. 5a-c) results from compositional variability in various regions of the crystals (Table 2 ). The main $M$ site component is typically $\mathrm{Co}$, with variable amounts of $\mathrm{Mg}$ and $\mathrm{Ni}$, while Fe, $\mathrm{Zn}$ and $\mathrm{Mn}$ occur only in traces. The $X$ site is filled mainly with As and minor amounts of P. In BSE images, the light grey erythrite zones are most enriched in Co [2.44(8) apfu on average], but also contain a significant presence of $\mathrm{Mg}$ [0.35(5) apfu]. The grey zones
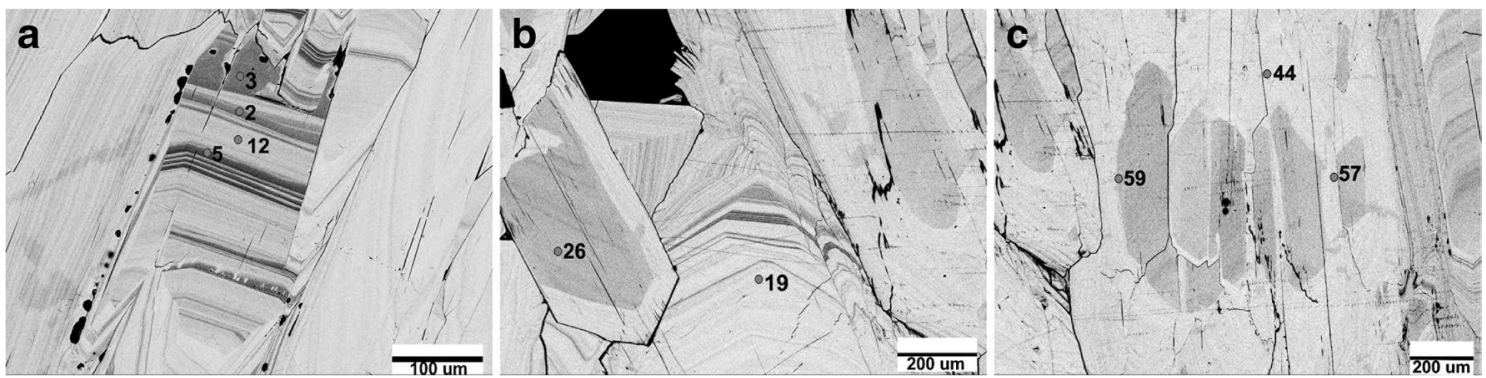

Fig. 5 BSE images of Mg-enriched erythrite with characteristic zoning and analytical points (see Table 2) 
Fig. 6 PXRD pattern of Mgenriched erythrite (black line) compared with the standard XRD discrete pattern of synthetic erythrite, card no. 33-413 from the ICDD database (red dashed lines) *- Si used as internal standard

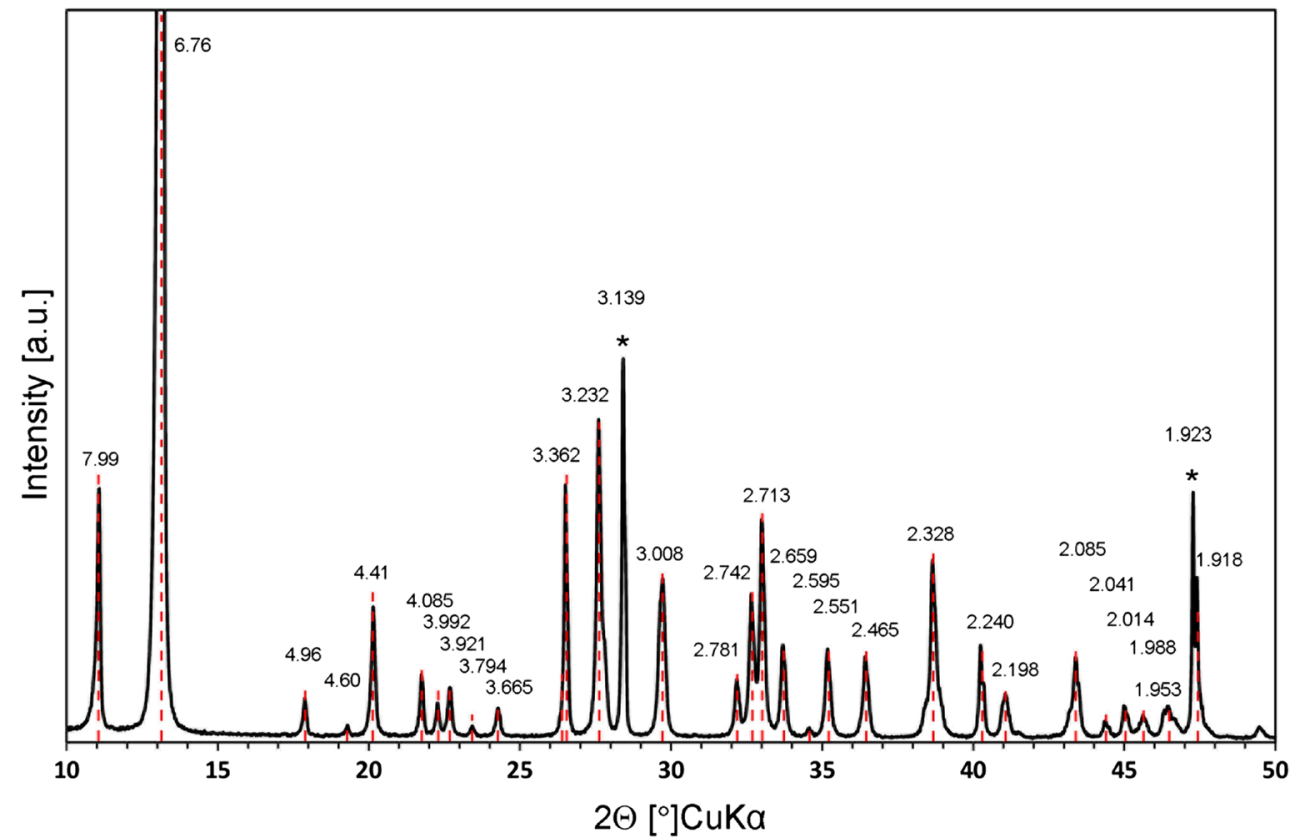

Fig. 7 DTA-TG-DTG-QMS curves of Mg-enriched erythrite

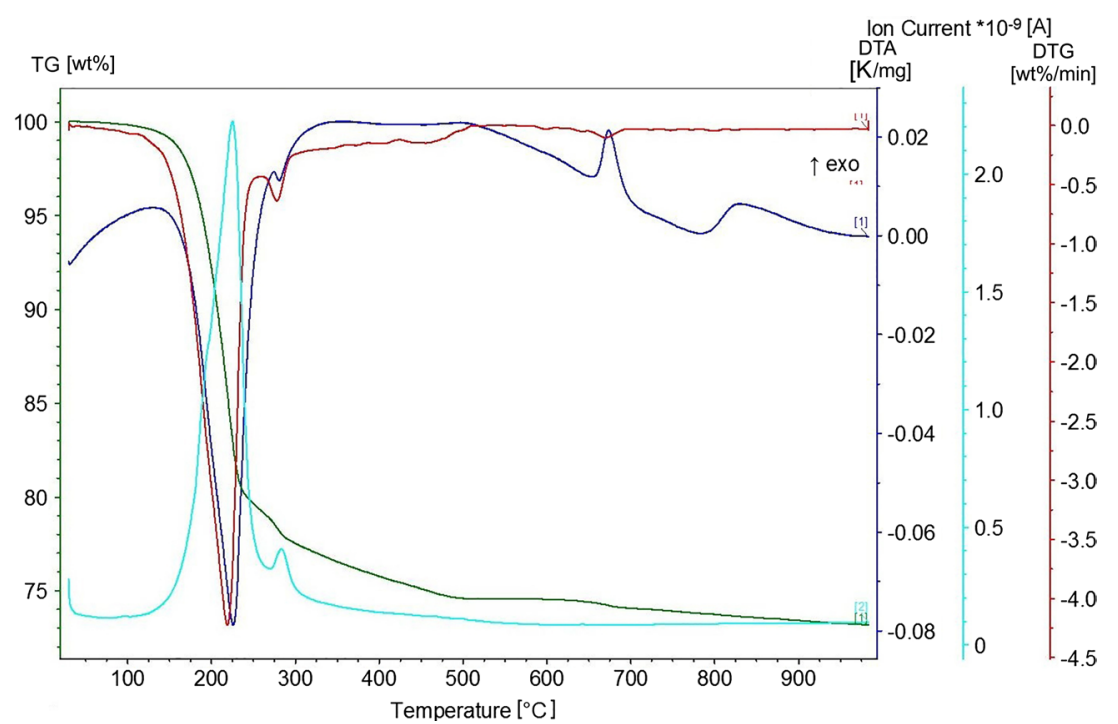

of Mg-bearing erythrite contain $\mathrm{Mg}$ [0.61(7) apfu] and somewhat lower amounts of Co [2.18(6) apfu], whereas the dark grey zones of $\mathrm{Mg}$-rich erythrite are significantly enriched in $\mathrm{Mg}$ [1.34(6) apfu on average] and strongly depleted in Co [1.50(6) apfu], with only a small surplus of Co over $\mathrm{Mg}$. The contents of Ni (0.13-0.15 apfu on average) are relatively similar in all zones. The individual zones also differ in the contents of trace elements such as $\mathrm{Fe}$ and $\mathrm{Mn}$. The light grey and grey zones are enriched in Mn (0.02-0.05 apfu) and Fe (0.07-0.03 apfu), whereas the dark grey zones are depleted in these elements $(<0.01$ apfu and 0.02 apfu, respectively). The compositional variation among zones is also presented in Fig. 8, as a spatial distribution of $\mathrm{Mg}, \mathrm{Ni}, \mathrm{Co}, \mathrm{Fe}$ and $\mathrm{As}$, within a small area of the erythrite crystal presented in Fig. 5.

\section{Raman microspectroscopy}

Generally, the studied erythrite is characterized by diagnostic bands at 3200, 3048, 858, 797, 442, 392, 253, 210 and $152 \mathrm{~cm}^{-1}$ (Fig. 9; Table 3). In the water-stretching region, at least three broad bands are observed at about 3436, 3200 and $3048 \mathrm{~cm}^{-1}$. The two higher-energetic bands are assigned to $B_{g}$, whereas the latter is assigned to $A_{g}$ modes (Martens 
Table 2 Selected compositions of various zones of Mg-enriched erythrite by EPMA

\begin{tabular}{|c|c|c|c|c|c|c|c|c|c|c|c|c|c|c|c|}
\hline \multirow{2}{*}{$\begin{array}{l}\text { Sample zones* } \\
\text { Analysis number }\end{array}$} & \multicolumn{3}{|c|}{ Dark grey zones $(n=4)$} & \multirow[t]{2}{*}{ Average } & \multirow[t]{2}{*}{$\mathrm{Sd}$} & \multicolumn{3}{|c|}{ Grey zones $(n=16)$} & \multirow[t]{2}{*}{ Average } & \multirow[t]{2}{*}{$\mathrm{Sd}$} & \multicolumn{3}{|c|}{$\begin{array}{l}\text { Light grey zones } \\
(\mathrm{n}=17)\end{array}$} & \multirow[t]{2}{*}{ Average } & \multirow[t]{2}{*}{$\mathrm{Sd}$} \\
\hline & 2 & 3 & 5 & & & 26 & 59 & 57 & & & 19 & 12 & 44 & & \\
\hline \multicolumn{16}{|l|}{ Oxides (wt\%) } \\
\hline $\mathrm{P}_{2} \mathrm{O}_{5}$ & 0.00 & 0.00 & 0.00 & 0.02 & 0.03 & 0.00 & 0.03 & 0.09 & 0.02 & 0.04 & 0.05 & 0.00 & 0.00 & 0.03 & 0.04 \\
\hline $\mathrm{As}_{2} \mathrm{O}_{5}$ & 41.53 & 41.63 & 41.04 & 41.74 & 0.72 & 40.35 & 39.51 & 40.02 & 39.87 & 0.52 & 39.32 & 39.15 & 39.06 & 39.27 & 0.70 \\
\hline $\mathrm{CoO}$ & 20.54 & 21.01 & 20.66 & 20.95 & 0.47 & 28.26 & 27.85 & 28.16 & 28.54 & 0.72 & 31.98 & 32.52 & 31.35 & 31.42 & 0.98 \\
\hline $\mathrm{NiO}$ & 2.02 & 1.94 & 1.97 & 2.02 & 0.09 & 2.24 & 1.76 & 2.15 & 1.96 & 0.49 & 1.92 & 0.99 & 1.61 & 1.65 & 0.38 \\
\hline $\mathrm{MgO}$ & 10.23 & 10.02 & 10.07 & 9.88 & 0.47 & 4.80 & 4.52 & 4.04 & 4.26 & 0.49 & 2.44 & 2.21 & 2.29 & 2.45 & 0.37 \\
\hline $\mathrm{FeO}$ & 0.12 & 0.20 & 0.14 & 0.19 & 0.07 & 0.36 & 0.41 & 0.42 & 0.43 & 0.08 & 0.52 & 0.73 & 0.85 & 0.64 & 0.13 \\
\hline $\mathrm{ZnO}$ & 0.02 & 0.08 & 0.13 & 0.08 & 0.05 & 0.02 & 0.47 & 0.47 & 0.27 & 0.13 & 0.19 & 0.07 & 0.26 & 0.20 & 0.08 \\
\hline $\mathrm{MnO}$ & 0.00 & 0.00 & 0.00 & 0.00 & 0.00 & 0.20 & 0.25 & 0.60 & 0.39 & 0.16 & 0.25 & 0.20 & 0.27 & 0.29 & 0.11 \\
\hline $\mathrm{H}_{2} \mathrm{O}^{* *}$ & 26.33 & 26.40 & 26.11 & 26.39 & 0.26 & 25.48 & 24.97 & 25.24 & 25.20 & 0.24 & 24.98 & 24.72 & 24.70 & 24.81 & 0.21 \\
\hline Total & 100.79 & 101.28 & 100.12 & 101.28 & 1.15 & 101.71 & 99.77 & 101.19 & 100.94 & 0.96 & 101.65 & 100.59 & 100.39 & 100.76 & 0.79 \\
\hline \multicolumn{16}{|c|}{ Calculated formula*** (apfu) } \\
\hline $\mathrm{P}$ & 0.00 & 0.00 & 0.00 & 0.00 & 0.00 & 0.00 & 0.00 & 0.01 & 0.00 & 0.00 & 0.00 & 0.00 & 0.00 & 0.00 & 0.00 \\
\hline As & 1.98 & 1.98 & 1.97 & 1.98 & 0.02 & 1.99 & 1.98 & 1.99 & 1.98 & 0.01 & 1.97 & 1.99 & 1.98 & 1.98 & 0.03 \\
\hline$\sum X$ & 1.98 & 1.98 & 1.97 & 1.98 & 0.02 & 1.99 & 1.99 & 1.99 & 1.99 & 0.01 & 1.98 & 1.99 & 1.98 & 1.99 & 0.03 \\
\hline Co & 1.50 & 1.53 & 1.52 & 1.53 & 0.06 & 2.13 & 2.15 & 2.15 & 2.18 & 0.06 & 2.46 & 2.53 & 2.44 & 2.44 & 0.08 \\
\hline $\mathrm{Ni}$ & 0.15 & 0.14 & 0.15 & 0.15 & 0.01 & 0.17 & 0.14 & 0.16 & 0.15 & 0.04 & 0.15 & 0.08 & 0.13 & 0.13 & 0.03 \\
\hline $\mathrm{Mg}$ & 1.39 & 1.36 & 1.38 & 1.34 & 0.06 & 0.67 & 0.65 & 0.57 & 0.61 & 0.07 & 0.35 & 0.32 & 0.33 & 0.35 & 0.05 \\
\hline $\mathrm{Fe}$ & 0.01 & 0.01 & 0.01 & 0.01 & 0.01 & 0.03 & 0.03 & 0.03 & 0.03 & 0.01 & 0.04 & 0.06 & 0.07 & 0.05 & 0.01 \\
\hline $\mathrm{Zn}$ & 0.00 & 0.01 & 0.01 & 0.01 & 0.00 & 0.00 & 0.03 & 0.03 & 0.02 & 0.01 & 0.01 & 0.00 & 0.02 & 0.01 & 0.01 \\
\hline $\mathrm{Mn}$ & 0.00 & 0.00 & 0.00 & 0.00 & 0.01 & 0.02 & 0.02 & 0.05 & 0.03 & 0.01 & 0.02 & 0.02 & 0.02 & 0.02 & 0.01 \\
\hline$\sum \mathrm{A}$ & 3.05 & 3.05 & 3.07 & 3.03 & 0.06 & 3.02 & 3.02 & 3.00 & 3.02 & 0.03 & 3.04 & 3.01 & 3.01 & 3.01 & 0.07 \\
\hline $\mathrm{H}_{2} \mathrm{O}$ & 8 & 8 & 8 & 8 & & 8 & 8 & 8 & 8 & & 8 & 8 & 8 & 8 & \\
\hline
\end{tabular}

Sd, Standard deviation

* Greyscales of sample zones refer to observed BSE intensities

** Calculated from stoichiometry

*** Calculated on the basis of $8 \mathrm{O}$ atoms per formula unit (apfu), with the assumed presence of $8 \mathrm{H}_{2} \mathrm{O}$ molecules pfu

et al. 2004). Bands at 3200 and $3048 \mathrm{~cm}^{-1}$ result from the presence of so-called water II, which has short hydrogenbonding distances, whereas the band at $3436 \mathrm{~cm}^{-1}$ is due to water I, with long hydrogen-bonding distances (Martens et al. 2004). The most intensive bands in Raman spectra of erythrite are found at $858\left(\mathrm{~A}_{\mathrm{g}}\right)$ and $797\left(\mathrm{~A}_{\mathrm{g}}\right) \mathrm{cm}^{-1}$. They are connected with $\nu_{3}$ and $\nu_{1}$ arsenate anti-symmetric and symmetric stretching vibrations, respectively (Rojo et al. 1996; Makreski et al. 2015), although Frost et al. (2003) and Martens et al. $(2004,2005)$ interpreted these modes inversely. The other bands at $442\left(\mathrm{~A}_{\mathrm{g}}\right)$ and $392\left(\mathrm{~B}_{\mathrm{g}}\right) \mathrm{cm}^{-1}$ are assigned to $\nu_{4}$ anti-symmetric bending and $\nu_{2}$ symmetric bending arsenate modes. The Raman active bands at lower wavenumbers of $253\left(\mathrm{~A}_{\mathrm{g}}\right), 210\left(\mathrm{~A}_{\mathrm{g}}\right)$ and $152 \mathrm{~cm}^{-1}\left(\mathrm{~B}_{\mathrm{g}}\right)$ are attributed to lattice vibrations (Frost et al. 2003b; Martens et al. 2004; Makreski et al. 2015).

For detailed chemical characteristic of erythrite from Bou Azzer, the Raman spectra were recorded separately for two analytical spots significantly differing in $\mathrm{Mg}$ contents $(0.32$ and 1.39 apfu of $\mathrm{Mg}$; see Table 2, Analyses 2 and 12). The most distinct difference is noted in the region from about 790 to $890 \mathrm{~cm}^{-1}$, where the two most intensive $\nu_{1}$ and $\nu_{3}$ bands are located (Fig. 9). For zones with an extreme of $1.39 \mathrm{apfu}$ of $\mathrm{Mg}$ in the structure, these bands occur at 865 and $800 \mathrm{~cm}^{-1}$ and are shifted towards higher wavenumbers, compared to Co-richer zones of the crystals.

\section{Discussion}

Mg-enriched erythrite, coexisting with skutterudite, roselite and alloclasite within a partly altered pneumo-hydrothermal matrix in the ophiolite sequence of Bou Azzer, is a secondary supergene mineral, formed by the oxidation of the primary skutterudite. Ahmed et al. (2009a) noted that oreforming elements, such as $\mathrm{Co}, \mathrm{Ni}, \mathrm{Fe}$ and $\mathrm{As}$, were originally leached from serpentinites by acidic magmatic fluids under moderately reducing conditions at high fluid/rock ratios. 
Fig. 8 BSE image and compositional WDXS maps of a fragment of an Mg-enriched erythrite crystal shown in Fig. $5 b$
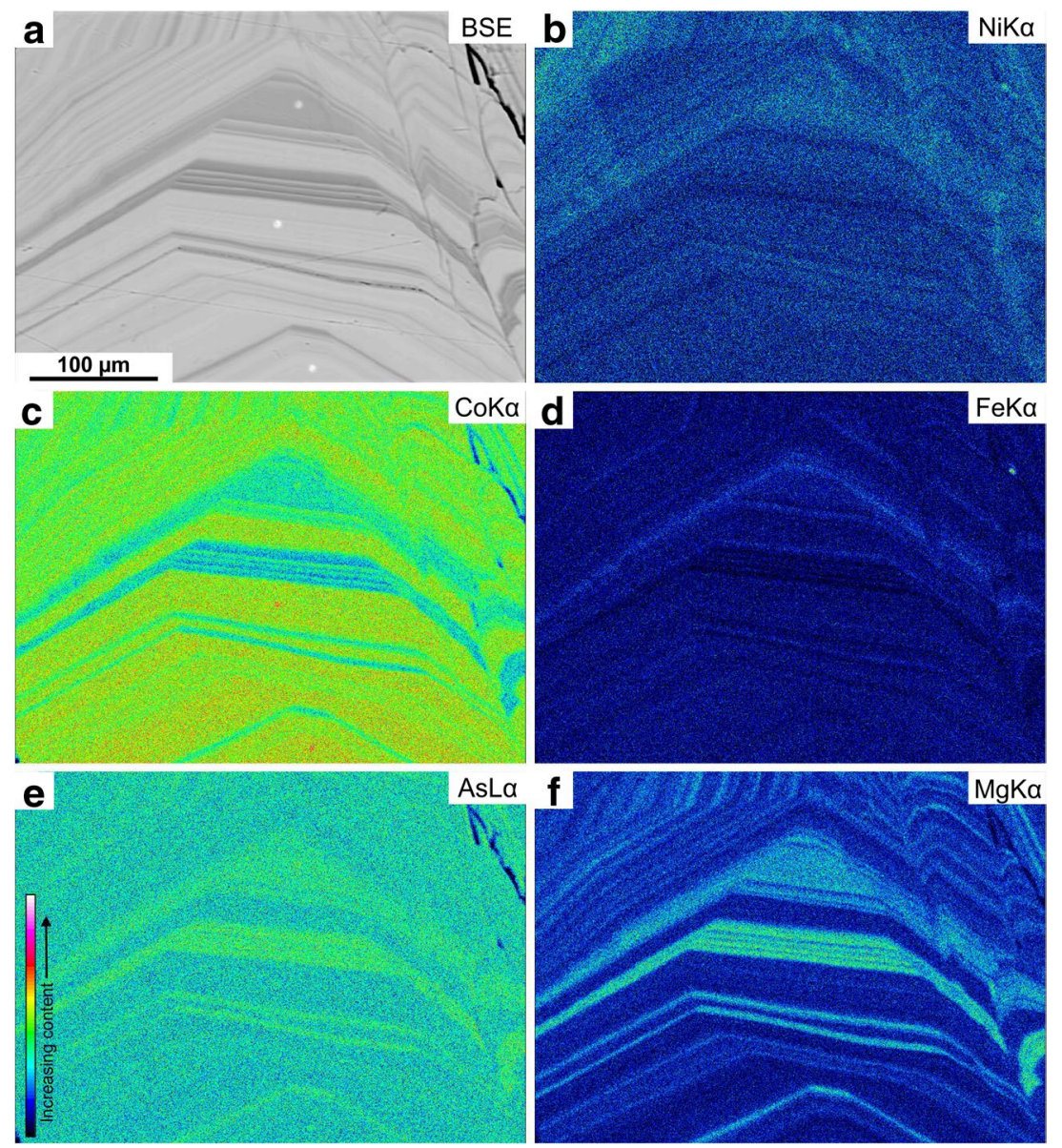

Fig. 9 Raman spectra recorded for the individual zones of Mg-enriched erythrite (blue line obtained in a bright $\mathrm{BSE}$ region, red line in a dark BSE region; vide Fig. 8a)

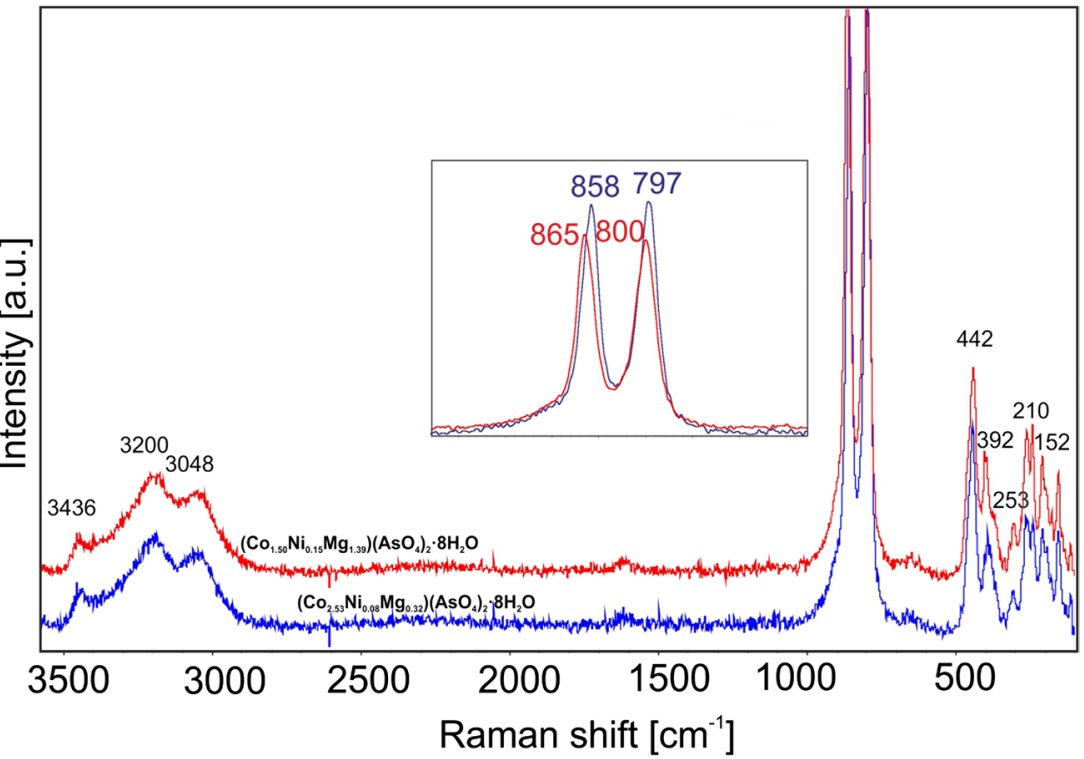

This was followed by the deposition of ore minerals occurring in response to increasing $\mathrm{pH}$ and decreasing oxygen fugacity in the mineralizing fluids, caused by a mixing of the magmatic brines and meteoric water.
The oxidation of sulphides, arsenides and arsenosulphides releases large amounts of mobile $\mathrm{SO}_{4}{ }^{2-}$ and $\mathrm{AsO}_{4}{ }^{3-}$ ions, which decreased $\mathrm{pH}$ in the oxidation zone, into the groundwater. These acidic solutions promote the 
Table 3 Assignment of Raman bands for Mg-enriched erythrite

\begin{tabular}{lll}
\hline Raman bands & Assignment & References \\
\hline 3436 & $\mathrm{~B}_{\mathrm{g}}$ (O-H stretching) & Martens et al. (2004) \\
3200 & $\mathrm{~B}_{\mathrm{g}}$ (O-H stretching) & Martens et al. (2004) \\
3048 & $\mathrm{~A}_{\mathrm{g}}$ (O-H stretching) & Martens et al. (2004) \\
$865(858)$ & $\mathrm{A}_{\mathrm{g}}$ (As-O anti-symmetric stretching) & Rojo et al. (1996) \\
$800(797)$ & $\mathrm{A}_{\mathrm{g}}$ (As-O symmetric stretching) & Rojo et al. (1996) \\
442 & $\mathrm{~A}_{\mathrm{g}}$ (As-O anti-symmetric bending) & Frost et al. (2003b, 2004) \\
392 & $\mathrm{~B}_{\mathrm{g}}$ (As-O symmetric bending) & Frost et al. (2003b, 2004) \\
253 & $\mathrm{~A}_{\mathrm{g}}$ external vibration & Frost et al. (2003b, 2004) \\
210 & $\mathrm{~A}_{\mathrm{g}}$ external vibration & Frost et al. (2003b, 2004) \\
152 & $\mathrm{~B}_{\mathrm{g}}$ external vibration & Frost et al. (2003b, 2004) \\
\hline
\end{tabular}

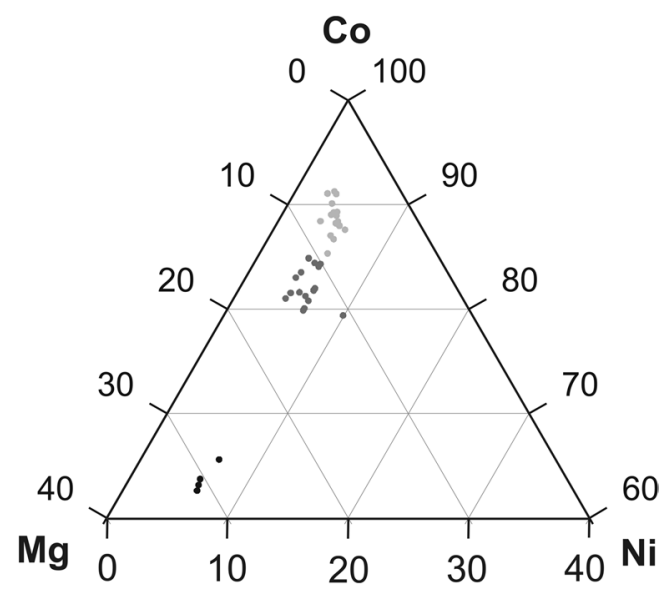

Fig. 10 Compositional variation of $\mathrm{Mg}$-enriched erythrite (wt\%) plotted on a Co-Mg-Ni triangle diagram. Colours of symbols refer to BSE intensities analogous to Table 2

further decomposition of the primary ore mineralization and the host rocks connected with the liberation of cations of various metals. In the Bou Azzer region, $\mathrm{CO}^{2+}, \mathrm{Ni}^{2+}$ and $\mathrm{Fe}^{2+}$-bearing solutions influence gangue minerals in the progressive release of $\mathrm{Na}^{+}, \mathrm{Ca}^{2+}, \mathrm{Mg}^{2+}, \mathrm{Al}^{3+}$ and other cations.

The crystallization of Mg-enriched erythrite with oscillatory zoning is strongly constrained by crystal chemistry and the crystal-liquid equilibrium. This results from the periodic changes in the solution composition, i.e., fluctuating activities of the mobilized cations in solutions of the oxidation zone and disequilibrium in their diffusion to the growing crystal. Moreover, intrinsic (e.g., adsorption of growth inhibitors) and extrinsic mechanisms (e.g., fluctuation of redox conditions) during mineralizing episodes could be responsible for the production of such a characteristic texture (Shore and Fowler 1996). The possible source of Mg in the $\mathrm{Mg}$-enriched erythrite structure was local groundwater bearing $\mathrm{Mg}^{2+}$ from numerous dolomite veins outcropping in Bou Azzer.
Capitelli et al. (2007) refined the crystal structure of $\mathrm{Mg}$-rich erythrite of the composition $\left(\mathrm{Co}_{2.16} \mathrm{Ni}_{0.24} \mathrm{Mg}_{0.60}\right)_{\Sigma 3}\left(\mathrm{AsO}_{4}\right)_{2} \cdot 8 \mathrm{H}_{2} \mathrm{O}$ coming from Bou Azzer. The oscillatory multi-zoned crystals studied by us also represent an erythrite-dominated solid solution with hörnesite and annabergite endmembers (Fig. 10). They are composed of thin zones of the dominant composition $\left(\mathrm{Co}_{2.44} \mathrm{Ni}_{0.13} \mathrm{Mg}_{0.35} \mathrm{Fe}_{0.05} \mathrm{Mn}_{0.02} \mathrm{Zn}_{0.01}\right)_{\Sigma 3}\left(\mathrm{AsO}_{4}\right)_{2} \cdot 8 \mathrm{H}_{2} \mathrm{O}$, alternated with zones of the Mg-richer composition of $\left(\mathrm{Co}_{2.18} \mathrm{Ni}_{0.15} \mathrm{Mg}_{0.61} \mathrm{Fe}_{0.03} \mathrm{Mn}_{0.03} \mathrm{Zn}_{0.02}\right)_{\Sigma 3.02}\left(\mathrm{AsO}_{4}\right)_{2} \cdot 8 \mathrm{H}_{2} \mathrm{O}$, and with rare discontinuous $\mathrm{Mg}$-richest zones with compositions graded at $\left(\mathrm{Co}_{1.50} \mathrm{Ni}_{0.15} \mathrm{Mg}_{1.39} \mathrm{Fe}_{0.01}\right)_{\Sigma 3.01}\left(\mathrm{AsO}_{4}\right)_{2} \cdot 8 \mathrm{H}_{2} \mathrm{O}$. The first two compositions are comparable to the erythrite species from Bou Azzer, as described by Capitelli et al. (2007); however, the latter, according to the present authors, represents erythrite with the highest $\mathrm{Mg}$ content ever reported to date. Wildner et al. (1996) investigated erythrite from Schneeberg in Saxony, significantly enriched in $\mathrm{Fe}^{2+}$, which substituted for Co in this species. The Fe deficiency in Mg-enriched erythrite is probably due to the Fe impoverishment of the primary Co ores in Bou Azzer. The significant predominance of $\mathrm{Co}$ over $\mathrm{Ni}$ in the $\mathrm{Mg}$-enriched erythrite structure, despite the high Ni/Co ratio of the Bou Azzer serpentinites being the source of these elements, may be attributed to the different solubility of $\mathrm{Ni}$ and $\mathrm{Co}$ in hydrothermal systems (Co is more soluble than $\mathrm{Ni}$ ), as suggested by Ahmed et al. (2009a).

The calculated hypothetical $\mathrm{H}_{2} \mathrm{O}$ content (average $25.58 \mathrm{wt} \%$ ) in $\mathrm{Mg}$-rich erythrite crystals is similar to the value of $23 \mathrm{wt} \%$ of total water measured by DTA-QMS analyses. The release of water by dehydration of the $\mathrm{Mg}$ enriched erythrite structure proceeded in two steps with maxima DTG peaks at 220 and $275^{\circ} \mathrm{C}$, leading firstly to the partly dehydrated phase $(\mathrm{Co}, \mathrm{Mg})_{3}\left(\mathrm{AsO}_{4}\right)_{2} \cdot 2 \mathrm{H}_{2} \mathrm{O}$, and then to anhydrous $(\mathrm{Co}, \mathrm{Mg})_{3}\left(\mathrm{AsO}_{4}\right)_{2}$, similar to pure, synthetic erythrite, as noted by Frost et al. (2004). The presence of two independent water molecules is also well reflected by active hydroxyl bands in Raman spectra of the mineral. 
Water type II with short hydrogen-bonding distances is detected at low wavenumbers of about 3200 and $3048 \mathrm{~cm}^{-1}$, while the high wavenumber band at $3436 \mathrm{~cm}^{-1}$ is due to water I with long hydrogen-bonding distances. The most intensive Raman bands of 865 and $800 \mathrm{~cm}^{-1}$, originating from $\nu_{3}$ and $\nu_{1}$ As-O anti-symmetric and symmetric stretching vibrations, recorded in the extreme $\mathrm{Mg}$-rich zone, are shifted towards higher wavenumbers in comparison with 'normal' erythrite (858 and $\left.797 \mathrm{~cm}^{-1}\right)$. The shifting is interpreted as a result of $\mathrm{Mg} \rightarrow$ Co substitution in the $M$ sites leading to the hörnesite, which shows the respective Raman bands at 875 and $807 \mathrm{~cm}^{-1}$ (Frost et al. 2003b; Martens et al. 2004; Makreski et al. 2015; RRUFF database).

According to Martens et al. (2004), the $v_{3}$ and $\nu_{1}$ stretching vibrations of the As-O bond in the $\mathrm{AsO}_{4}$ group shift to lower wavenumbers with decreasing ionic radii and increasing cation mass. Comodi et al. (2001) suggested that, as a bond increased in strength, the vibrational frequency should also have increased. The mean distance of As-O bond was refined in arsenates, such as erythrite at $1.694 \AA$ (Wildner et al. 1996) and $1.710 \AA$ (Antao and Dhaliwal 2017), Mgenriched erythrite at $1.693 \AA$ (Capitelli et al. 2007), annabergite at $1.691 \AA$ (Wildner et al. 1996), and at $1.714 \AA$ in a synthetic member of the hörnesite-annabergite solid solution (Rojo et al. 1996). Thus, the substitution $\mathrm{Mg} \rightarrow \mathrm{Co}(\mathrm{Ni})$ at the $M 1$ and $M 2$ sites enlarges the As-O bond, meaning that Raman wavenumbers of the $\nu_{3}$ and $\nu_{1}$ stretching vibrations should decrease. Therefore, the positions of $\nu_{3}$ and $\nu_{1}$ stretching vibration bands in hörnesite, as well as shifting these bands towards higher wavenumbers in Mg-rich erythrite, seem to be in contradiction to their band positions. The $\nu_{3}$ and $\nu_{1}$ band positions in erythrite and annabergite were discussed by Martens et al. $(2004,2005)$ in terms of the influence of the $M$ cations $\left(\mathrm{Co}^{2+}, \mathrm{Ni}^{2+}, \mathrm{Mg}^{2+}\right)$ being different due to atomic mass (58.93 vs. 58.69 vs. 24.31 , respectively) and ionic radius $(0.65 \AA$ vs. $0.69 \AA$ vs. $0.72 \AA$, respectively). However, no simple combination of these parameters explains why wavenumbers of the $\nu_{3}$ and $\nu_{1}$ Raman bands are distinctly higher for hörnesite $\left(875\right.$ and $\left.807 \mathrm{~cm}^{-1}\right)$ than erythrite ( 852 and $792 \mathrm{~cm}^{-1}$ ) or annabergite (832 and $795 \mathrm{~cm}^{-1}$ ) (all spectroscopic data from Frost et al. 2003).

To explain the observed shifting of $\nu_{3}$ and $\nu_{1}$ bands in hörnesite (and Mg-rich erythrite) towards higher wavenumbers, both for cation radii and their masses, as well as the positive charge of atomic nucleuses forming the bond, should be taken into account. In all minerals of the vivianite group, the As-O bond is modified by $\mathrm{Me}^{2+}$ cations bonded to the same oxygen as $\mathrm{As}^{5+}$. Thus, for hörnesite, the bond can be presented as As-O...Mg, for erythrite as As-O...Co and for annabergite as As-O...Ni. In the case of the not-fully spherical distribution of electrons around As (33 electrons around the nucleus), its positive charge draws the electron density from the As-O bond, thereby offsetting the potential increased bond strength arising from the contraction of the As-O bond. The charge balance around the $\mathrm{O}$ atom, forming the bond to As, is secured by $\mathrm{Me}$ atoms: $\mathrm{Mg}$ in hörnesite (12 electrons), Co in erythrite (27 electrons) and $\mathrm{Ni}$ in annabergite (28 electrons). This also affects the distribution of electrons around the oxygen atom. However, due to differences in charges of the nuclei, the contraction of the As-O bond is greater if the $M$ sites are filled with $\mathrm{Mg}$ (the difference between the charge of As and $\mathrm{Mg}$ nuclei is equal to 16 valence units [vu]), as well as relative $\mathrm{Co}$ and $\mathrm{Ni}$ (the differences are equal only to 6 and $5 \mathrm{vu}$, respectively). As a consequence, the As-O bond strength is highest when the $M$ sites are occupied with $\mathrm{Mg}$. The influence of atomic masses of the $M e$ atoms, as discussed in the literature (Martens et al. 2004, 2005), may also affect the positions of the $\nu_{3}$ and $\nu_{1}$ bands, especially in comparisons of erythrite and annabergite, for which the oxygen-coordinated $\mathrm{Me}$ atoms (Co and $\mathrm{Ni}$ ) differ only by $1 \mathrm{vu}$. However, in the case of the presence of $\mathrm{Mg}$ at the $M$ sites, as in hörnesite, or a partial substitution of $\mathrm{Co}$ or $\mathrm{Ni}$ by $\mathrm{Mg}$ in erythrite or annabergite, the difference in charges of the nuclei (As, Mg), which simultaneously form bonds with the same oxygen, seems to be the most important feature shifting the $\nu_{3}$ and $\nu_{1}$ bands towards higher wavenumbers.

As expected, unit cell parameters, as refined by us, for the powdered sample are similar to the values obtained by Capitelli et al. (2007). They are also close to pure synthetic erythrite and erythrite species, devoid of magnesium, from other localities worldwide (e.g., Wildner et al. 1996; http://www.mindat. org). This similarity is a result of only a small variation in the unit cell parameters of erythrite and hörnesite $[a=10.254$ (3) $\AA$ vs. $10.262 \AA$, respectively; $b=13.477$ ((4) $\AA$ vs. $13.442 \AA$, $c=4.764(1) \AA$ vs. $4.741 \AA$, and $\beta=104.98^{\circ}$ vs. $104.9^{\circ}$ ] (http:// www.mindat.org), along with an intermediate position concerning the studied erythrite in the solid solution with hörnesite.

\section{Conclusions}

Three key results were obtained in the present study. First, Mg-enriched erythrite from Bou Azzer, with a fine oscillatory zoning texture, contains fine zones with an exceptionally high $\mathrm{Mg}$ content [up to 1.39(6) apfu]. To the best of our knowledge, this $\mathrm{Mg}$ content is higher than any other value reported for any erythrite species worldwide. The source of $\mathrm{Mg}$ was probably dolomite, coexisting with Asbearing minerals, as a gangue to ores of this region. Second, the increased content of $\mathrm{Mg}$ and the zoned texture of the Mg-enriched erythrite, observed in BSE images, do not distinctly influence the optical features and unit cell parameters of this mineral. Third, the increased $\mathrm{Mg}$ in the erythrite structure shifts Raman-active $\nu_{3}$ and $\nu_{1}$ As-O stretching bands from 858 to $797 \mathrm{~cm}^{-1}$ towards higher Raman shifts 
(i.e., up to 865 and $800 \mathrm{~cm}^{-1}$, respectively) in zones of $\mathrm{Mg}$ richest erythrite with the composition $\left(\mathrm{Co}_{1.50} \mathrm{Ni}_{0.15} \mathrm{Mg}_{1.39}\right.$ $\left.\mathrm{Fe}_{0.01}\right)_{\Sigma 3.01}\left(\mathrm{AsO}_{4}\right)_{2} \cdot 8 \mathrm{H}_{2} \mathrm{O}$. The shifting corresponds to an intermediate position of the present samples within the erythrite-hörnesite solid solution. It is suggested that the shifting is a result of not-fully spherical distribution of electrons around the As nucleus, which draws the electron density from the As-O bond towards As. This contracts the As-O bond, while increasing its strength. As the same $\mathrm{O}$ atoms also participate in the $\mathrm{Me}-\mathrm{O}$ bond $(\mathrm{Me}=\mathrm{Mg}, \mathrm{Co}, \mathrm{Ni})$, the contraction of the As-O is strongest for $M e=\mathrm{Mg}$, due to the highest difference in positive charges of the nuclei of both elements.

Acknowledgements The erythrite samples studied here were kindly provided by the gem collectors Jacek Szczerba, Jolanta Szczerba and Jaroslav Prsek, who obtained the specimens during their field trips in 2011, 2012 and 2013. Tomasz Paraszkier is acknowledged for providing valuable information on the geology of the Bou Azzer region, as well as numerous photos of Bou Azzer mineralization. The authors are also grateful to Justyna Ciesielczuk and Francesco Capitelli for their substantial and constructive remarks, which helped to improve the manuscript, as well as to Anton Beran and Lutz Nasdala for their editorial comments. Andrew Wygralak is thanked for proofreading the first version of the text. The work was financially supported by the AGH University of Science and Technology (Krakow, Poland), research project no. 11.11.140.319.

Open Access This article is distributed under the terms of the Creative Commons Attribution 4.0 International License (http://creativecommons.org/licenses/by/4.0/), which permits unrestricted use, distribution, and reproduction in any medium, provided you give appropriate credit to the original author(s) and the source, provide a link to the Creative Commons license, and indicate if changes were made.

\section{References}

Ahmed AH, Arai S, Ikenne M (2009a) Mineralogy and paragenesis of the Co-Ni arsenide ores of Bou Azzer, Anti-Atlas, Morocco. Econ Geol 104:249-266

Ahmed AH, Arai S, Abdel-Aziz YM, Ikenne M, Rahimi A (2009b) Platinum-group elements distribution and spinel compositionin podiform chromitites and associated rocks from the upper mantle section of the Neoproterozoic Bou Azzer ophiolite, Anti-Atlas, Morocco. J Afr Sci 55:92-104

Antao SM, Dhaliwal I (2017) Growth oscillatory zoning in erythrite, ideally $\mathrm{Co}_{3}\left(\mathrm{AsO}_{4}\right)_{2} \cdot 8 \mathrm{H}_{2} \mathrm{O}$ : structural variations in vivianite-group minerals. Minerals 7(136):1-13

Anthony JW, Bideaux RA, Bladh KW, Nichols MC (2000) Handbook of mineralogy. IV Arsenates, phosphates, vanadates. Mineral Data Publishing, Tucson, p. 680

Capitelli F, Elaatmani M, Lalaoit MD, Piniella JF (2007) Crystal structure of a vivianite-type mineral: $\mathrm{Mg}$-rich erythrite, $\left(\mathrm{Co}_{2.16} \mathrm{Ni}_{0.24} \mathrm{Mg}_{0.60}\right)\left(\mathrm{AsO}_{4}\right)_{2} \cdot 8 \mathrm{H}_{2} \mathrm{O}$. Z Krist-Cryst Mater 222(12):676-679

Capitelli F, Chita G, Ghiara MR, Rossi M (2012) Crystal-chemical investigation of $\mathrm{Fe}_{3}\left(\mathrm{PO}_{4}\right)_{2} .8 \mathrm{H}_{2} \mathrm{O}$ vivianite minerals. $\mathrm{Z}$ Krista 227:92-101
Ciesielczuk J, Szełęg E, Kuźniarski M, Bylin P (2004) Preliminary data of erythrite from Ciechanowice (Miedzianka Deposit, Sudetes Mts.). Mineral Soc Poland Spec Publ 24:123-126

Comodi P, Liu Y, Frezzotti ML (2001) Structral and vibrational behaviour of fluorapatite with pressure Part II: In situ Micro-Raman spectroscopic investigation. Phys Chem Miner 28:225-231

En-Naciri A, Barbanson L, Touray JC (1997) Brine inclusions from the $\mathrm{Co}-\mathrm{As}(\mathrm{Au})$ Bou Azzer district, Anti-Atlas Mountains, Morocco. Econ Geol 92:360-367

Földvàri M (2011) Handbook of the thermogravimetric system of minerals and its use in geological practice. Occasional Papers of the Geological Institute of Hungary 213:1-179

Frost RL, Weier ML, Martens W, Kloprogge JT, Ding Z (2003a) Thermal decomposition of the vivianite arsenates - implications for soil remediation. Thermochim Acta 403:237-249

Frost RL, Kloprogge T, Weier ML, Martens WN, Ding Z, Edwards GH (2003b) Raman spectroscopy of selected arsenates - implications for soil remediation. Spectrochim Acta A 59:2241-2246

Frost RL, Martens W, Kloprogge JT (2004) Synthetic deutereted erythrite-a vibrational spectroscopy study. Spectrochim Acta A 60(1-2):343-349

Gasquet D, Levresse G, Cheilletz A, Azizi-Samir MR, Mouttaqi A (2005) Contribution to a geodynamic reconstruction of the AntiAtlas (Morocco) during Pan-African times with the emphasis on inversion tectonics and metallogenic activity at the PrecambrianCambrian transition. Precambrian Res 140(3-4):157-182

Gilliam SJ, Clifton NM, Scott JK, Jensen JO, Zeroka D, Banerjee A (2003) Raman spectroscopy of arsenolite: crystalline cubic $\mathrm{As}_{4} \mathrm{O}_{6}$. J Solid State Chem 173:54-58

Hawkins M (July 2006) Cobalt News. The Cobalt Development Institute

Jambor JL, Dutrizac JE (1995) Solid solutions in the annabergiteerythrite-hörnesite synthetic system. Can Mineral 33:1063-1071

Kolkovski B, Petrov P, Dobrev S (2003) Hydrothermal ore-bearing features of igneous intrusive complexes. Annual of the University of Mining and Geology "St. Ivan Rilski”, Sofia Bulgaria 46:65-76

Leblanc M (1975) Ophiolites précambriennes et gîtes arseniés de cobalt (Bou Azzer-Maroc). Unpublished Ph.D. thesis, Paris, France, Université de Paris VI:367 pp

Leblanc M (1976) Proterozoic oceanic crust at Bou Azzer. Nature 261:34-35

Leblanc M (1981) The Late Proterozoic ophiolites of Bou Azzer (Morocco): Evidence for Pan-African plate tectonics. In: Kröner A (ed) Precambiarn Plate tectonics. Developments in Precambrian geology, vol 4. Elsevier, Amsterdam, pp 435-451

Leblanc M, Billaud P (1982) Cobalt arsenide orebodies related to anupper Proterozoic ophiolite, Bou Azzer (Morocco). Econ Geol 77(1):162-175

Leblanc M, Fischer W (1990) Gold and platinum group elements in cobalt arsenide ores: Hydrothermal concentration from a serpentinite source-rock. Miner Petrol 42:197-209

Leblanc M, Lbouabi M (1988) Native silver mineralization along a rodingite tectonic contact between serpentine and quartz diorite (Bou Azzer, Morocco). Econ Geol 83:1379-1391

Lhoest J (1995) The Kipushi mine. Zaire Mineral Rec 26:163-192

Makreski P, Stefov S, Pejov L, Jovanovski G (2015) Theoretical and experimental study of the vibrational spectra of (para)symplesite and hörnesite. Spectrochim Acta A 144:155-162

Marshall D, Watkinson DH (2000) The cobalt mining district: Silver. Sources: Transport and deposition. Explor Min Geol 9:81-90

Martens WN, Kloprogge JT, Frost RL, Rintoul L (2004) Single-crystal Raman study of erythrite, $\mathrm{Co}_{3}\left(\mathrm{AsO}_{4}\right)_{2} \cdot \mathrm{H}_{2} \mathrm{O}$. J Raman Spectrosc 35(3):208-216

Martens WN, Kloprogge JT, Frost RL, Rintoul L (2005) Site occupancy of $\mathrm{Co}$ and $\mathrm{Ni}$ in erythrite-annabergite solid solutions deduced by vibrational spectroscopy. Can Mineral 43(3):1065-1075 
Rojo JM, Mesa JL, Pizarro JL, Lezama L, Arriortua MI, Rojo T (1996) Spectroscopic and magnetic study of the $(\mathrm{Mg}, \mathrm{M})_{3}\left(\mathrm{AsO}_{4}\right) \cdot 8 \mathrm{H}_{2} \mathrm{O}$ $\left(\mathrm{M}=\mathrm{Ni}^{2+}, \mathrm{CO}^{2+}\right)$ arsenates. Mater Res Bull 31(8):925-934

Shore M, Fowler AD (1996) Oscillatory zoning in minerals; a common phenomenon. Can Mineral 34:111-1126

Smith CG (2001) Always the bridesmaid, never the bridge: Cobalt geology and resources. Appl Earth Sci: Transactions of the Institutions of Mining Metallurgy: Section B 110(2):75-80

Vidmar LJ (2011) Cobalt: Characteristics, Compounds and Applications. Chemical Engineering Methods and Technology, Earth Sciences in the 21st Century, Vova Press
Wilde A, Simpson I, Hanna S (2002) Preliminary study of Cenozoic hydrothermal alteration and platinum deposition in the Oman ophiolite. Journal of the Virtual Explorer 6:7-13

Wildner M, Giester G, Lengauer CL, McCammon CA (1996) Structure and crystal chemistry of vivianite-type compounds: Crystal structure of erythrite and annabergite with a Mössbauer study of erythrite. Eur J Mineral 8:187-192 